\title{
Pengaruh Karawitan terhadap Totalitas Ekspresi Dalang dalam Pertunjukan Wayang Golek Menak Yogyakarta
}

\author{
Dewanto Sukistono ${ }^{1}$ \\ Jurusan Pedalangan Fakultas Seni Pertunjukan, Institut Seni Indonesia Yogyakarta
}

\begin{abstract}
ABSTRAK
Tulisan ini dimaksudkan untuk menjelaskan pengaruh karawitan sebagai salah satu pendukung utama pergelaran wayang dengan kualitas ekspresi dalang wayang golek Menak Yogyakarta. Keberadaan wayang golek Menak di Yogyakarta diawali pada tahun 1950-an yang dipopulerkan oleh Ki Widiprayitna, satu-satunya dalang wayang golek Menak pada waktu itu. Kesederhanaan gaya pedesaan Ki Widiprayitna dalam setiap pergelaran tidak mengurangi keberhasilannya dalam memainkan boneka wayang tiga dimensi tersebut, hingga ia mendapat julukan dhalang nuksmèng wayang. Salah satu faktor yang mempengaruhi keberhasilannya adalah kesatuan rasa antara gerak wayang dengan karawitan sebagai salah satu pendukung utama pertunjukan.
\end{abstract}

Kata kunci: karawitan, dalang, wayang, golek Menak

\begin{abstract}
The Influence of Karawitan towards the Expression Totality of Puppeteer in the Performances of Wayang Golek Menak Yogyakarta. This paper is intended to explain the effect of the karawitan as one of a principal supporter of wayang performance to the quality of the puppeteer expression towards wayang golek Menak Yogyakarta. The existence of wayang golek Menak Yogyakarta has been started in the early 1950's and was popularized by Ki Widiprayitna, the only puppeteer wayang golek Menak at that time. The simplicity of rustic styles of Ki Widiprayitna in every performances does not diminish his success in playing the three-dimensional puppets, until finally he gets the nickname of dhalang nuksmeing wayang. One of the factors that may influence his success is the unity of sense between the puppet motions with the karawitan as one of the principal supporters of performances.
\end{abstract}

Keywords: karawitan, puppeteer, wooden puppet, golek Menak

\section{Pendahuluan}

Wayang golek Menak adalah pertunjukan wayang golek yang menggunakan Serat Ménak sebagai sumber cerita. Selain wayang golek Menak, di Jawa terdapat beberapa jenis wayang golek dengan sumber cerita yang berbeda, seperti wayang golek Purwa dengan sumber cerita Mahabharata dan Ramayana, wayang golek Wacana Winardi dengan sumber cerita Kitab Perjanjian Lama, wayang golek dengan cerita babad, Panji, maupun yang bersumber dari cerita-cerita lokal di daerahdaerah tertentu. Wayang golek dengan berbagai macam sumber cerita tersebut tersebar hampir di seluruh pulau Jawa, misalnya di Jawa Tengah dapat ditemukan di Tegal, Pekalongan, Pemalang, Brebes, Cilacap, Purbalingga, Kebumen, Purworejo, Pati, Kudus, dan Blora. Di Yogyakarta terdapat di Kulon Progo, Bantul dan Sleman. Di Jawa Timur antara lain terdapat di Tuban, Situbondo, dan Bojonegoro. Di Jawa Barat misalnya terdapat di Bandung, Sumedang, Cibiru, Padalarang, Kerawang, Sukabumi, Ciranjang, Cipanas, Cirebon, dan sebagainya.

Sampai penelitian ini dilakukan belum dapat ditemukan sumber tertulis yang mengungkap secara pasti tentang asal-usul keberadaan wayang golek. Informasi awal yang menjelaskan tentang hal tersebut adalah di dalam Serat Centhini yang diungkapkan melalui bentuk tembang Salisir

Alamat korespondensi: Jurusan Pedalangan Fakultas Seni Pertunjukan ISI Yogyakarta, Jln. Parangtritis km. 6,5 Yogyakarta. Tlp: (0274) 375380. E-mail: dsukistono@yahoo.com 
dengan sengkalan: Wayang Nir Gumuling Kisma, serta dalam Serat Sastramiruda berbentuk gancaran dengan sengkalan Wayang Sirna Gumuling Kisma. Kata nir dan sirna sebenarnya mempunyai makna atau arti yang sama, yaitu hilang, kosong, dan atau terjemahan lain untuk menunjuk angka 0 (nol). Kata nir barangkali dipakai untuk menyesuaikan jumlah guru wilangan dalam tembang macapat. Brandon (2003: 65) secara singkat juga menyatakan bahwa menurut legenda wayang golek diciptakan Sunan Kudus pada tahun 1584.

Wayang golek Menak Yogyakarta berbentuk tiga dimensi dengan bahan utama dari kayu, dapat dibagi menjadi tiga bagian pokok, yaitu bagian kepala, bagian badan lengkap dengan tangan, serta bagian kain penutup. Hampir semua tokoh wayang golek memakai baju berlengan panjang tanpa bentuk kaki. Bagian kepala dan badan dihubungkan dengan sebuah tangkai yang disebut sogol, sedangkan untuk menggerakkan kedua tangan wayang digunakan sepasang tuding. Di Yogyakarta dan sekitarnya, keberadaan wayang golek Menak dipelopori oleh Ki Widiprayitna pada periode tahun 1950-an sampai dengan 1960an, satu-satunya dalang wayang golek Menak di Yogyakarta pada waktu itu.

Secara umum, struktur pertunjukan wayang golek Menak Yogyakarta masih mengacu pada pertunjukan wayang kulit purwa gaya Yogyakarta, terutama dalam hal pathet berkaitan dengan pembagian adegannya, yaitu pathet Nem, pathet Sanga dan pathet Manyura. Beberapa ricikan atau instrumen gamelan lengkap yang biasanya digunakan dalam pergelaran wayang golek Menak adalah: gendèr barung, gendèr penerus, slenthem, kendhang, bonang barung, bonang penerus, gambang, suling, siter, rebab, kethuk kenong, kempul gong, demung, saron, serta peking. Selain itu, masih ada sebuah instrumen khas dari wayang golek Menak Yogyakarta yang disebut rojèh. Instrumen ini berupa dua lempengan besi berbentuk segi empat, permukaannya dibuat agak cekung dengan tebal masing-masing sekitar tiga milimeter, disusun bertumpuk beralaskan papan kayu. Alat ini dibunyikan dengan cara dipukul dengan gandhèn yang terbuat dari kayu, atau bisa juga dengan palu besi sehingga menim- bulkan suara yang sangat keras. Alat ini berfungsi untuk memberikan penekanan rasa terutama dalam adegan perang untuk menghasilkan kesan kerasnya benturan yang disebabkan oleh pukulan, tendangan, bantingan, dan sebagainya.

Menurut Katidja Wirapramudja seperti dikutip Sukarno, dalang wayang golek Menak Yogakarta dan juga merupakan putera Ki Widiprayitna, salah satu faktor yang sangat digemari masyarakat pada waktu itu adalah kemampuan Ki Widiprayitna dalam memainkan wayang kelihatan hidup, sehingga ia dijuluki dhalang nuksmèng wayang (wawancara, 20 Juni 2014). Keberhasilan pergelaran $\mathrm{Ki}$ Widiprayitna dalam mencapai tataran dhalang nuksmèng wayang tentu saja tidak bisa dilepaskan dari keberadaan dan dukungan iringan karawitan yang menggunakan instrumen gamelan sebagai salah satu pendukung pokok pertunjukan. Karawitan adalah seni suara baik vokal maupun instrumental yang menggunakan tangga nada sléndro dan pélog (Martopangrawit, 1975:1). Pada awalnya ricikan instrumen gamelan yang digunakan pada masa Ki Widiprayitna hanya menggunakan gamelan laras sléndro saja dengan perbendaharaan gending-gending yang sangat sederhana, namun pada masa Ki Sukarno kadangkadang juga mengunakan laras pélog.

Penelitian ini selain mengungkap persoalan bentuk dan struktur gending-gending khas yang digunakan pada pertunjukan wayang golek Menak Yogyakarta, juga mengungkap konsep-konsep garap karawitan berkaitan dengan fungsinya sebagai pendukung utama dalang untuk mencapai tataran kualitas tertinggi estetika rasa dalam setiap pertunjukannya, yaitu dhalang nuksmèng wayang. Topik yang spesifik ini dipilih mengingat sebagai sebuah pertunjukan wayang, fungsi karawitan tidak sekedar mengiringi, tetapi juga sangat berperan dalam menghidupan baik dalam karakterisasi tokoh maupun suasana adegan. Kekuatan karawitan dalam menghidupan pergelaran bukan semata-mata terletak pada kerumitan teknis maupun banyaknya jenis gending yang digunakan, melainkan pada kesatuan rasa antara karakter musikal karawitan dengan ekspresi ragam gerak wayang. Hal menarik lainnya dalam konteks ini 
bahwa pencapaian kesatuan rasa antara pengrawit dan dalang bukan semata-mata berdasarkan tingkat kemahiran pengrawit, tetapi lebih kepada keberhasilan komunikasi sambung rasa antara dalang dan pengrawit.

\section{Bentuk dan Struktur Gending Wayang Golek Menak Yogyakarta}

Hastanto (2009: 13) menjelaskan bahwa gamelan merupakan perangkat fisik ansambel musik yang ricikannya didominasi oleh ricikan bersumber bunyi dengan bahan logam (perunggu) yang dilaras di dalam 2 (dua) sistem pelarasan yaitu laras sléndro dan laras pélog. Kecuali ricikan bersumber bunyi logam perunggu, di dalam gamelan juga terdapat ricikan dengan sumber bunyi kayu, ada pula dawai (baik yang dipetik maupun digesek), udara (ricikan tiup), dan ricikan membrane. Selanjutnya dijelaskan bahwa dasar proses musikalisasi gamelan meliputi: 1) laras, yaitu sistem pengaturan frekuensi dan interval nada-nada; 2) embat, yaitu suasana atau atmosfer musikal yang disebabkan karena struktur interval dalam pelarasan gamelan; dan 3) pathet, yaitu suasana atau atmosfer musikal yang disebabkan karena rasa sèlèh pada nada-nada tertentu dalam sebuah lagu hasil dari rangkaian nada-nada pembentuk lagu itu sendiri (Hastanto, 2009: 22). Lagu-lagu yang disajikan oleh gamelan baik secara instrumental saja maupun dengan vokal biasa disebut dengan gending (gendhing) (Hastanto, 2009:47-48).

Di dalam dunia karawitan ada banyak istilah yang berkaitan langsung dengan gending, misalnya berdasarkan bentuknya yaitu gending alit, gending ageng, dan gending pamijèn. Gending berdasarkan ricikan yang memimpin seperti gending rebab, gending gendèr, gending bonang, dan gending gambang. Gending yang dibentuk berdasarkan sekar atau tembang biasa disebut dengan gending sekar. Ada juga istilah gending kemanak kethuk kenong, yaitu gending yang hanya terdapat pada gending bedhayan. Istilah gending berdasarkan fungsinya misalnya gending pakurmatan yaitu gending yang digunakan dalam sebuah upacara untuk menghormati salah satu mata acara dalam upacara itu. Con- toh gending pakurmatan adalah gending Kodhok Ngorèk yang dimainkan pada saat acara temu dalam upacara perkawinan. Gending klenèngan, yaitu sajian gending-gending yang khusus untuk didengarkan. Di dalam gending klenèngan masih ada kelompok kecil 'anak' dari gending klenèngan yang disebut gending manguyu-uyu yang dimainkan untuk menanti kedatangan tamu. Gending wayangan yaitu gending yang digunakan pada pertunjukan wayang kulit, sedangkan gending beksan digunakan untuk sajian tari-tarian tradisional (Hastanto, 2009: 48-49). Bentuk dan struktur gending yang digunakan dalam pertunjukan wayang biasanya terdiri dari tiga macam, yaitu gending alit yang terdiri dari lancaran, ketawang, dan ladrang, gending ageng yang biasanya bentuk gending kethuk 2 kerep, serta gending khusus misalnya ayak-ayakan, srepegan, serta sampak.

Kekhasan dramaturgi wayang tradisi terutama terletak pada pola penyajian yang selalu terbagi menjadi wilayah pathet, untuk gaya Surakarta dan Yogyakarta yaitu pathet nem, pathet sanga, serta pathet manyura. Pembagian wilayah ini sesuai dengan wilayah pathet laras gamelan yang digunakan kaitannya dengan waktu pertunjukan, meskipun kadang-kadang pembagian waktu setiap wilayah pathet tidak selalu persis sama. Becker seperti dikutip Soedarsono (1997: 213) menyatakan bahwa karena adanya hubungan tak terpisahkan antara pembagian dalam struktur dramatik dengan gamelan yang mengiringinya, istilah pathet sendiri akhirnya juga berarti 'bagian' atau act. Pola penyajian wayang golek Menak semalam suntuk secara umum mengacu pada pola penyajian wayang kulit purwa gaya Yogyakarta, terutama dalam pembagian wilayah pathet, meskipun tidak semua urutan adegan ditampilkan. Di dalam wayang kulit purwa semalam suntuk, terdapat tujuh jejeran dan beberapa adegan yang dijabarkan ke dalam masingmasing wilayah pathet tersebut. Setiap jejeran atau adegan menggunakan repertoar bentuk gendhing tertentu sesuai dengan wilayah pathet, apabila tidak menggunakan gendhing tetapi hanya merupakan bentuk srepegan maka dinamakan gladhagan.

Rincian tujuh jejeran tersebut adalah sebagai berikut. (a) Pathet nem terdiri atas jejer pisan, adegan 
kedhatonan, adegan muja semèdi, adegan pasowanan njawi yang dirangkai dengan bidhalan dan perang ampyak, jejer pindho, dan jejer telu; (b) Pathet sanga dimulai setelah suwuk gendhing yang mengawali jejer telu. Setelah jejer telu dilanjutkan dengan adegan gara-gara yaitu tampilnya panakawan Semar, Gareng, Petruk, dan Bagong. Sesudah garagara dilanjutkan dengan jejer papat serta jejer lima; dan (c) Pathet manyura, terdiri atas jejer nem dan jejer pitu (Mudjanattistomo, dkk., 1977:161).

Pada dasarnya di dalam pergelaran wayang golek Menak Yogyakarta mempunyai perbendaharaan gending-gending tersendiri sesuai dengan wilayah pathet dan berbeda dengan wayang kulit purwa. Bentuk khas tersebut khususnya di dalam jejer pertama selalu menggunakan gending Ketawang Gendhing Kabor Topèng Laras Sléndro Pathet Nem dilanjutkan inggah ladrang. Selain dilanjutkan dengan inggah ladrang, untuk jejer sabrang atau tokoh dengan karakter gagahan bisa juga dilanjutkan dengan bentuk inggah Lancaran Béndrong yang diisi dengan motif-motif gerak kiprahan. Di dalam wilayah Pathet Nem, gendinggending khas wayang golek Menak Yogyakarta adalah ayak-ayak Kembang Jeruk Sléndro Pathet Nem, srepeg Kembang Jeruk Sléndro Pathet Nem, Sampak Gosongan Sléndro Pathet Nem. Di dalam wilayah Pathet Sanga, terdapat beberapa bentuk gending yang khas misalnya Ayak-ayak Kembang Jeruk Sléndro Pathet Sanga, Srepeg Kembang Jeruk Sléndro Pathet Sanga, Srepeg Gedhog Sléndro Pathet Sanga untuk adegan perang, Sampak Gosongan Sléndro Pathet Sanga. Sedangkan untuk wilayah Pathet Manyura terutama bentuk gending srepegan yaitu srepeg Gégot, Srepeg Gambuh, Srepeg Sastradatan, Sampak Sastradatan, serta Sampak Gosongan. Bentuk ayak-ayakan biasanya menggunakan Ayak-ayak Sléndro Manyura yang biasa dipergunakan dalam pergelaran wayang kulit purwa gaya Yogyakarta.

\begin{tabular}{|c|c|c|c|c|c|c|c|c|c|c|c|c|c|c|c|}
\hline \multirow{3}{*}{ Buka. } & \multicolumn{15}{|c|}{ Ktv. Gendhing Kabor Topèng SL Nem } \\
\hline & & .5 & 61 & 165 & 23 & & 532 & 16 & 3( & & & & & & \\
\hline & 3 & 2 & 1 & & 1 & 2 & 3 & 6 & 5 & 3 & 2 & 1 & 6 & 3 & 5 \\
\hline & 5 & 6 & i & 6 & 5 & 2 & 3 & 6 & 5 & 3 & 2 & 1 & 6 & 3 & (5) \\
\hline \multicolumn{12}{|c|}{ Inggab ladrang } & 5 & 6 & 5 & (3) \\
\hline & 66 & 5 & 2 & 5 & 6 & 5 & 3 & 5 & 6 & 5 & 2 & 5 & 6 & 5 & 3 \\
\hline 5 & 56 & 5 & 2 & 5 & 6 & 5 & 3 & 5 & 5 & 6 & 1 & 2 & 1 & 6 & (5) \\
\hline 6 & 55 & 6 & 1 & 2 & 1 & 6 & 5 & 6 & 5 & 6 & 1 & 2 & 1 & 6 & 5 \\
\hline 6 & 55 & 6 & 1 & 2 & 1 & 6 & 5 & 6 & 6 & 3 & 2 & 5 & 6 & 5 & (3) \\
\hline \multicolumn{4}{|c|}{ Suwne } & & & & & 5 & 5 & 6 & 1 & 2 & 1 & 6 & (5) \\
\hline
\end{tabular}

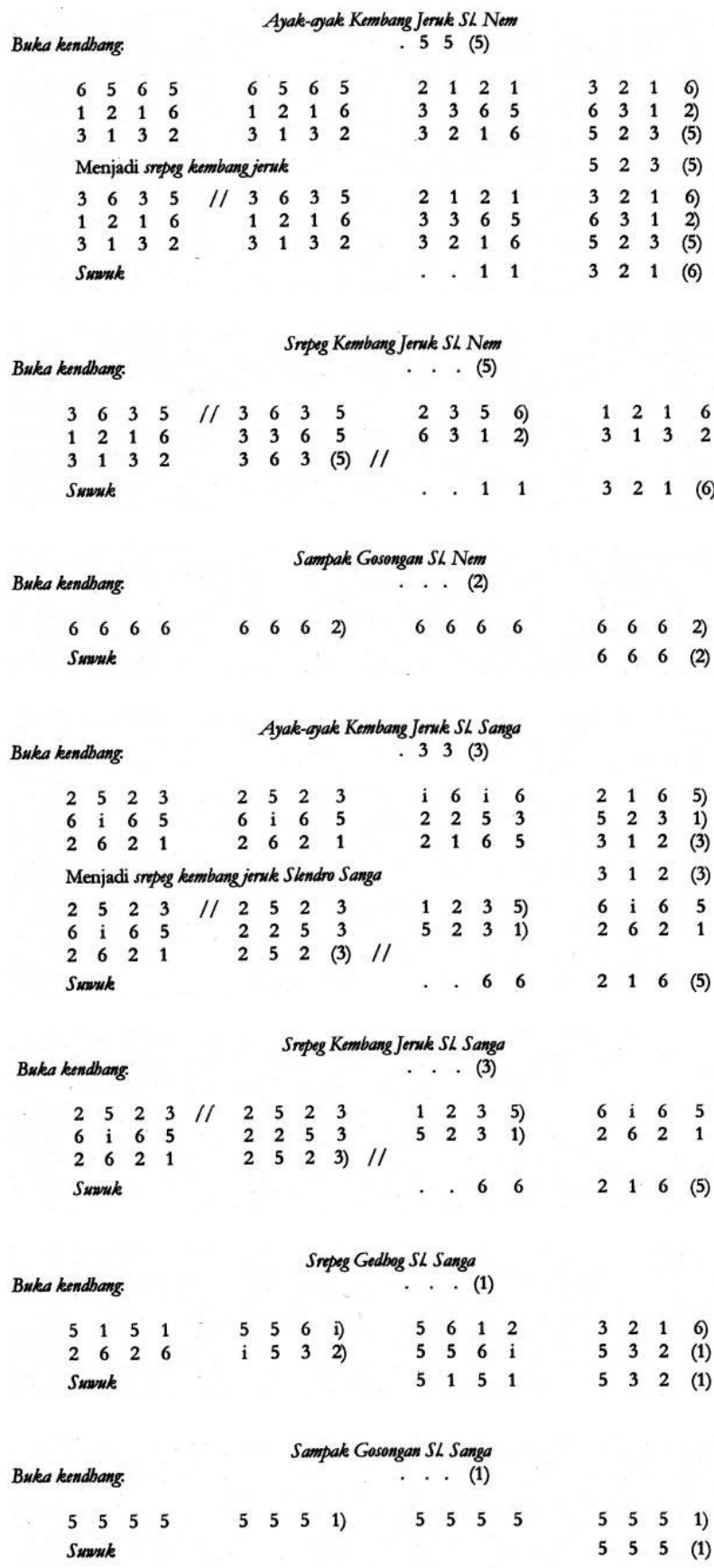

Srepeg Gégot SL Manywra

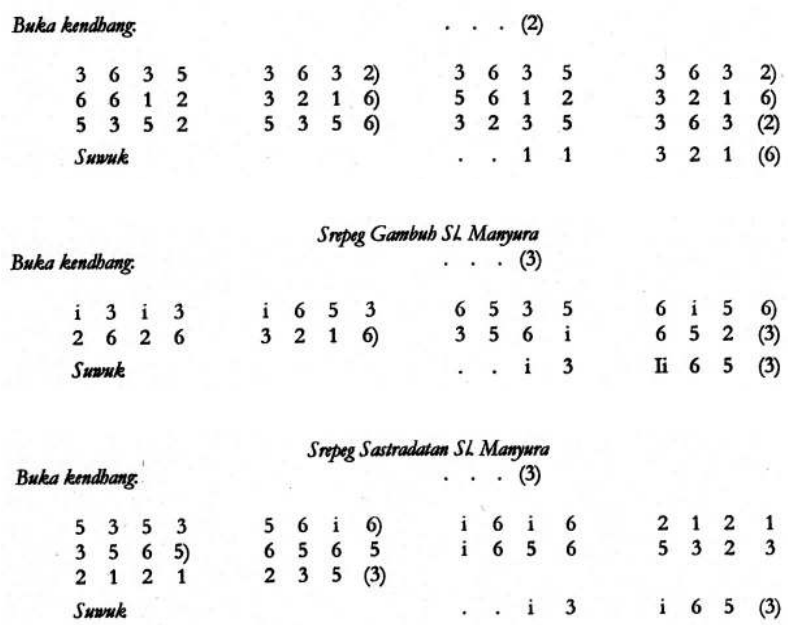



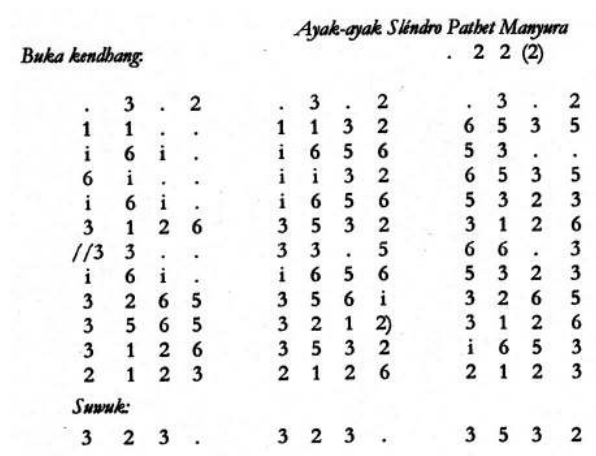

6 3 i $5{ }^{2} \quad 2$

$\begin{array}{lll}3 & 3 & 5\end{array}$

6 i 55 6)

$\begin{array}{llll}1 & 2 & 3 & 2 \text { ) } \\ 1 & 5 & 3 & (2)\end{array}$

$\begin{array}{llll}3 & 5 & 3 & 2)\end{array}$

$\begin{array}{lll}6 & \mathrm{i} & 9\end{array}$

3056 i

$\begin{array}{llll}3 & 5 & 3 & 2\end{array}$

$\begin{array}{llll}5 & 6 & \text { i } & 6 \\ 2 & 1 & 2 & 6 / 1\end{array}$

\section{Dhalang Nuksmèng Wayang: Puncak Estetika Rasa}

Istilah anuksma (Jawa Kuna: anūkşma) menurut berarti bersembunyi, menyembunyikan, mengerjakan dengan diam-diam (Mardiwarsito, 1978:319). Nuksmå juga berarti merasuk ke dalam sesuatu atau manjing (Tim Penyusun Balai Bahasa Yogyakarta, 2001:540). Nuksmå atau anuksmå memiliki tiga pengertian, yaitu: 1) hadir (tetapi) tidak tampak, berada di suatu kondisi immaterial yang menyebabkan dirinya tidak tampak; 2) masuk tanpa kelihatan ke dalam, menyembunyikan diri dalam, atau menghilang ke dalam sesuatu; 3) memasuki sesuatu sebagai esensinya yang tidak nampak, yaitu menjelma ke dalam sesuatu, mengambil bentuk luar dari sesuatu atau seolaholah seperti sesuatu (Zoetmulder dan Robson, 1995:1139).

Berdasarkan definisi tersebut maka julukan dhalang nuksmèng wayang bermaksud untuk menggambarkan pencapaian tataran tertinggi estetika rasa, kemampuan Ki Widiprayitna dalam memainkan wayang kelihatan 'hidup' seolah-olah wayang tersebut bergerak sendiri tanpa digerakkan. Di dalam konteks ini Ki Widiprayitna berhasil membuat transformasi dari bahasa verbal visual sebuah pertunjukan boneka realis tiga dimensi yang pada awalnya dinikmati oleh mata, menjadi bahasa imaginatif ketika penonton tidak sekedar menikmati ketrampilan teknis tetapi bisa merasakan greget atau pesan yang diungkapan melalui gerak wayang.

Berbicara tentang persoalan estetika, tentu akan selalu bersinggungan dengan masalah bentuk (form) yang menunjuk pada rasa (sense) dan isi (substance) yang menunjuk pada makna atau arti (meaning)( Dewey, 1958:131). Menurut Parker seperti dikutip Humardani (1980: 103-112), permasalahan teknik seni sebagian besar terletak pada cara menciptakan bentuk-bentuk visual dan auditif yang mampu membina penghayat hingga ia meletakkan arti-arti di dalamnya seperti yang diharapkan. Pada karya seni, unsur yang paling mampu menumbuhkan rasa hidup adalah daya bayangannya. Di manapun pada karya seni terdapat kecenderungan bahwa gagasan itu dibuat berisi, dijadikan konkrit dan hidup lewat bayangan.

Sebagai contoh, sewaktu melihat lukisan pemandangan di musim cerah, kita bukan hanya mengenal bahwa warna-warna itu berarti cahaya matahari melainkan sebenarnya juga merasakan kehangatan cahayanya. Sewaktu melihat patung wanita, kita bukan hanya menafsirkan permukaannya itu sebagai badan wanita, melainkan juga merasakan kehalusan dan kelumatannya. Ini berarti bahwa gagasan tentang cahaya matahari dan badan manusia itu disusun bersama dengan segala bayangan yang menjadi asalnya semula. Di dalam seni representasi, terutama pada lukisan dan pahat, bayangan asosiasi itu berbaur dengan sensasi penglihatan yang merupakan mediumnya. Hal ini disebabkan karena gagasan tentang benda yang disajikan dalam lukisan dan pahat itu seolah ada sesungguhnya dalam sensasi penglihatan yang ditafsirkan. Pada seni jenis ini persepsi estetik adalah penyatuan bayangan dan sensasi seperti halnya pada persepsi normal. Artinya, serealis apapun wayang golek dengan bentuknya yang tiga dimensi, yang memberikan kehidupan adalah daya bayangannya, bukan semata-mata pada ketrampilan teknisnya saja. Persoalannya bahwa untuk sampai pada pencapaian puncak estetika rasa tersebut, dalang harus didasari pada kemapanan teknis terlebih dahulu, tanpa ketrampilan teknis maka sangat mustahil untuk mencapainya, meskipun setelah sampai pada tataran tertinggi estetika rasa tersebut persoalan teknis menjadi tidak begitu penting, karena yang hadir adalah dimensi imajinatif, bukan lagi fisik.

Kualitas nuksma ditentukan oleh dua aspek, pertama dalang dengan kualitas ekspresi karya seninya, serta kedua adalah penonton dengan kualitas penghayatannya. Kedua aspek tersebut 
harus melebur menjadi satu atau manjing, nyawiji, luluh dalam sebuah pertunjukan, sehingga tidak ada lagi jarak karena dunia verbal yang ada berubah menjadi dunia ide atau imaginatif. Penghayatan penonton dapat mengantarkannnya bertransformasi ke dalam adegan bahkan menjadi tokoh dalam cerita yang dibawakan. Meskipun demikian di dalam konteks nuksma bukan berarti penonton harus selalu sependapat dengan pemaknaan yang disampaikan oleh dalang melalui garap pertunjukannya, misalnya dalam garap karakter tokoh wayang. Di dalam persoalan nuksma ini dalang tidak bisa menunjukkan tetapi hanya bisa melakukannya, sebaliknya penonton hanya mampu menunjukkan atau merasakan tetapi tidak mampu untuk menirukan atau melakukannya. Ekspresi nuksma adalah ekspresi sesaat dan sangat sulit untuk diulang kembali, seperti dinyatakan oleh Abdullah (2006: 58) bahwa sebuah seni yang baik tentu saja tidak ada kembarannya

Rasa berarti suasana, getah, sari, kenikmatan, enak, nada, sari, inti, maksud (Mardiwarsito, 1978:268). Poerwadarminta (1984: 802) menjelaskan arti rasa yaitu: (1) apa yang dialami oleh lidah atau badan (ketika kena sesuatu); (2) sifat suatu benda dan sebagainya yang mengadakan rasa; (3) apa yang dialami oleh hati atau batin; keadaan hati atau batin; (4) pertimbangan pikiran (hati) mengenai baik-buruk; benar-salah, dan sebagainya; pendapat; dan (5) kira-kira; agaknya; rupa-rupanya; barangkali. Sedyawati (2010: 128) menyatakan bahwa konsep seni yang terbukti bertahan sebagai konsep kunci adalah rasa. Melalui berbagai paparan analisis dinyatakan bahwa rasa merupakan sasaran akhir dari suatu ungkapan seni. Rasa adalah pengalaman penghayatan seni dimana kesiapan akal, budi, dan emosi menyatu untuk mewujudkan penikmatan seni. Dalam paparanpaparan tertentu dinyatakan bahwa kenikmatan penghayatan seni itu sama hakikatnya dengan kenikmatan penghayatan religius. Dalam kedua hal itu keterikatan pada penyerapan indrawi sudah dilampaui.

Geertz (1973: 134-136) menjelaskan bahwa rasa dalam budaya Jawa memiliki arti ganda, yaitu perasaan (feeling) dan makna (meaning). Sebagai perasaan, rasa diartikan sebagai salah satu pancaindra orang Jawa yaitu merasakan, dari keempat pancaindra yang lain yaitu mendengar, berbicara, membaui, dan melihat. Dari pancaindra 'merasakan' mengandung tiga segi 'perasaan' sehingga pandangan tentang kelima indra itu terpisah yaitu pencecapan cita-rasa pada lidah; sentuhan pada badan berkaitan dengan pancaindra peraba; dan perasaan emosional di dalam hati seperti kesedihan dan kebahagiaan. Cita-rasa sebuah pisang adalah rasa-nyata (pancaindra pengecap-lidah); suatu firasat adalah suatu rasa (pancaindra 'perasaan'); kesakitan adalah suatu rasa; dan rasa adalah suatu nafsu atau emosi. Sebagai makna, rasa diterapkan pada kata-kata di dalam sebuah surat, dalam sebuah puisi.

Rasa juga diterapkan pada tingkah laku pada umumnya: untuk menunjukkan muatan implisit, perasaan konotatif dari gerakan-gerakan tari, gerakgerik tata krama. Dalam arti kedua, arti semantis, rasa juga berarti makna terakhir, yakni makna terdalam yang dicapai seseorang dengan usaha mistis dan yang kejelasannya menjernihkan segala ambiguitas dari kehidupan duniawi. Rasa adalah kehidupan, apa saja yang memiliki rasa itu hidup, dan apa saja yang hidup itu memiliki rasa.

Di dalam wayang golek Menak Yogyakarta, terdapat tiga unsur pokok yang merupakan satu kesatuan dan tidak bisa dipisahkan sebagai konsep dasar pertunjukannya, yaitu bentuk, gerak, dan karakterisasi. Bentuk yang dimaksud adalah bentuk boneka wayang tiga dimensi dengan bahan, bentuk, dan teknik permainan yang sangat berbeda dibandingkan dengan wayang kulit dua dimensi. Gerak yang dimaksud adalah gerak wayang yang mempunyai ragam gerak tersendiri berdasarkan behan, bentuk, serta teknik permainan tersebut.

Karakterisasi atau penokohan dapat digambarkan secara langsung melalui ekspresi bentuk, gerak, antawacana atau percakapan wayang, dan secara tidak langsung melalui perjalanan cerita serta dukungan karawitan termasuk dhodhogan, keprakan, dan sulukan. Oleh karena itu karakterisasi ini merupakan unsur yang fleksibel, bisa berubahubah berkaitan dengan lukisan jalan pikiran, serta reaksi terhadap peristiwa seperti telah disinggung di depan, disesuaikan dengan kebutuhan garap lakon yang dibawakan. Dengan kata lain tokoh yang sama 
bisa mempunyai karakter yang berbeda dalam lakon yang sama maupun berbeda. Penguasaan dalang pada persoalan teknik atas ragam gerak berdasarkan bentuk wayang dan kemudian disatukan dengan penggarapan karakter, memerlukan dukungan dari karawitan agar suasana adegan sesuai dengan kebutuhan bisa lebih 'hidup', dalam bahasa wayang dikenal dengan istilah semu. .

\section{Sambung Rasa: Komunikasi antara Dalang dan Pengrawit}

Di dalam dunia pertunjukan wayang, lazim dikenal istilah atau perumpamaan yang menunjuk pada pentingnya keterkaitan atau hubungan antara karawitan dan dalang dalam konteks pertunjukan wayang, yaitu sosok penabuh instrumen gendèr dan kendhang sebagai bojon dhalang atau istri dalang. Bahkan pada masa dulu tidak jarang sosok penabuh gender biasanya dilakukan oleh seorang wanita yang juga merupakan istri dalang tersebut dalam kehidupan senyatanya. Begitu halnya dengan Ki Widiprayitna, penabuh gendèr yang selalu mengiringi dalam setiap pertunjukannya adalah istrinya sendiri, dan seringkali juga dilakukan oleh kerabat wanitanya atau anak perempuannya. Sukarno menjelaskan salah satu alasan bahwa penggendèr adalah wanita, baik itu isteri, saudara maupun anaknya dianggap lebih mengerti kondisi kebiasaan Ki Widiprayitna secara psikologis, baik dari kehidupan nyata seperti emosi, kesenangan, kemarahan dan sebagainya, atau dalam konteks pertunjukan lebih bisa memahami maksud atau karakter dalam mendalang.

Peran gender dalam pertunjukan memang lebih banyak memperkuat karakter yang berkaitan dengan suasana adegan, misalnya suasana sereng yang berkaitan dengan suasana tegang, marah, nges untuk suasana percintaan, kebahagiaan, regu untuk suasana keagungan, kewibawaan, kesedihan, dan sebagainya. Peran tersebut berkenaan dengan kepentingan dalang yang lebih bersifat indivual, ditunjukkan terutama dengan teknik permainan melodi instrumen gendèr berkaitan dengan vokal dalang seperti ada-ada, sulukan, atau untuk memberikan ilustrasi atau dikenal dengan istilah grimingan untuk memperkuat narasi serta dialog atau antawacana. Kualitas atau kekuatan penggendèr memberikan kehidupan atau rasa pada pertunjukan wayang bukan semata-mata terletak pada ketrampilan teknis permainan melodinya, tetapi pada ketepatan dalam memilih karakter musikalnya berkaitan dengan kebutuhan adegan.

Karakter musikal merupakan fenomena musikal yang terelasi dari sebuah permainan melodi, ritme, dan dinamika yang tergarap, terstruktur, dan terpola dengan kiat, model, dan gaya tertentu sehingga menghasilkan rasa tertentu pula (Ardana, 2013: 143). Scrutton seperti dikutip Irawan (2014: 19-20) menjelaskan bahwa mengurai musik dari unsure yang paling hakiki yaitu bunyi. Ia memberikan landasan atas musik sebagai organisasi musikal dan makna musikal. Menurutnya, nada, ritme, melodi, dan harmoni bukan sekedar bentukbentuk organisasi musikal, tetapi merupakan pengalaman musikal yang paling utama di dalam kebudayaan. Adapun makna musikal dapat ditemukan dengan menghubungkan unsur-unsur bunyi, nada, ritme, melodi, harmoni, tonalitas, bentuk, isi, nilai, analisa, ekspresi, pertunjukan, hingga kebudayaan.

Berbeda dengan gender, kendhang lebih banyak berperan secara komunal sebagai pemimpin untuk menghidupkan suasana terutama berkaitan dengan ekspresi sabetan atau gerak wayang dan melibatkan koordinasi dengan seluruh instrumen gamelan lainnya. Kelekatan antara 'warna' atau motif kendhangan dengan visualisasi ragam gerak wayang sangat mempengaruhi kualitas ekspresi rasa gerak yang diungkapkan. Soedarsono (1999: 160) menjelaskan bahwa gerak memiliki makna serta sentuhan emosional tertentu.

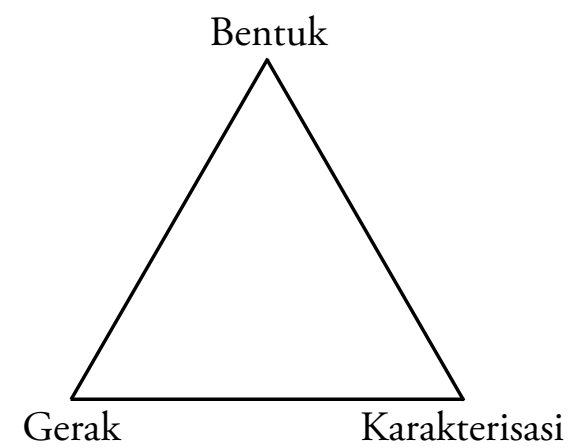

Gambar 1. Diagram piramida konsep dasar pertunjukan wayang golek Menak Yogyakarta (Dewanto Sukistono, 2013) 
Secara garis besar gerak bisa dibedakan menjadi dua, yaitu gerak keseharian dan gerak tari. Gerak tari adalah gerak yang telah mengalami distorsi atau stilisasi. Gerak tari, terutama dalam drama tari bisa dibedakan pula menjadi empat kategori, yaitu gerak maknawi (gesture), gerak murni (pure movement), gerak penguat ekspresi (baton signal), serta gerak yang khusus untuk berpindah tempat (locomotion). Gerak maknawi adalah gerak tari yang distilisasi dari gerak keseharian, yang secara jelas menggambarkan makna tertentu. Gerak murni adalah gerak yang hanya menitikberatkan pada keindahan semata, kadang-kadang digunakan untuk merangkai gerak maknawi yang satu dengan gerak maknawi lainnya. Gerak penguat ekspresi berfungsi untuk menambah ekspresi dari suatu maksud tertentu. Di dalam gerak maknawi ini masih bisa dicermati menjadi empat macam, yaitu pertama social mimicry atau gerak 'bermanis muka' untuk menutupi keadaan yang sebaliknya, contohnya tertawa padahal sedang bersedih. Kedua theatrical mimicry yaitu gerak sekedar sebagai hiburan. Ketiga partial mimicry yaitu gerak yang menirukan sesuatu yang tidak mungkin secara kenyataan dilakukannya, seperti menjadi burung, tetesan hujan dan sebagainya. Keempat vacuum mimicry yaitu gerak yang menirukan memegang sesuatu tetapi tidak ada barangnya (Moris, 1977: 28-29).

Gerak-gerak yang terdapat di dalam seni pertunjukan dimasukkan dalam kategori mimikri teatrikal (theatrical mimicry), yaitu gerak yang hanya menirukan gerak perilaku yang sesungguhnya (Soedarsono, 1999:161). Sesuai dengan bentuk boneka wayang golek tiga dimensi, maka secara teknis ragam gerak wayang golek berbeda dengan ragam gerak wayang kulit purwa. Ragam gerak wayang golek Menak yang dipopulerkan Ki Widiprayitna sebenarnya terinspirasi dari wayang topèng Pedhalangan Yogyakarta yang pada waktu itu cukup popular, yaitu pertunjukan drama tari topeng Panji yang dilakukan oleh para dalang dari berbagai daerah di wilayah Yogyakarta. Kepopuleran wayang topèng Pedhalangan pada waktu itu bersamaan waktunya dengan semangat Ki Wdiprayitna dalam mengembangkan wayang golek Menak Yogyakarta.
Gerak wayang golek Menak Yogyakarta pada dasarnya merupakan kombinasi antara gerak keseharian dan gerak yang telah mengalami distorsi atau stilisasi. Ragam gerak wayang golek Menak secara umum dapat dibedakan menjadi dua kategori, yaitu ragam gerak dasar dan ragam gerak perang. Masing-masing ragam gerak masih dibagi lagi menjadi dua, yaitu gerak dasar berpola dan gerak dasar tidak berpola, serta gerak perang berpola dan gerak perang tidak berpola. Ragam gerak dasar tidak berpola merupakan gerak-gerak lepas yang tidak terikat dengan pola karawitan, sedangkan ragam gerak dasar berpola merupakan rangkaian dari gerak-gerak dasar yang disusun menjadi sebuah struktur dan terikat dengan pola karawitan.

Gerak-gerak dasar tidak berpola pada umumnya merupakan penggambaran dari gerak-gerak keseharian, seperti berjalan, berlari, menggeleng, bernafas, dan sebagainya. Selain itu dapat juga berupa gerak keseharian yang telah mengalami distorsi atau stilisasi, berupa gerak-gerak maknawi seperti lumaksana atau berjalan, ulap-ulap atau melihat sesuatu, ngusap rawis atau mengusap kumis, dan sebagainya. Selain gerak maknawi ada juga gerak murni misalnya ongkèk, junjung sikil, seblak sampur, dan sebagainya. Gerak berpindah tempat yaitu srisig juga ditemukan dalam gerak dasar ini. Penguasaan kemampuan teknis yang memadahi ini serta didukung dengan ekspresi karakter musikal gending-gending iringannya akan berpeluang untuk menggiring hayatan penonton hingga sampai pada tataran rasa.

Ragam gerak dasar berpola adalah ragam gerak yang terikat dengan pola iringan, dalam hal ini terlihat jelas pada setiap adegan atau jejer yang menggunakan bentuk gendhing tertentu dengan menghadirkan beberapa tokoh secara berurutan. Ciri khas dari ragam gerak ini adalah adanya pola atau struktur gerak yang merupakan rangkaian dari gerak-gerak maknawi maupun gerak murni yang disusun secara berurutan. Struktur gerak ini ragam geraknya disesuaikan dengan setiap karakter tokoh yang tampil. Contoh ragam gerak dasar berpola ini adalah stuktur gerakan sabetan yang terdiri atas urutan gerak ulap-ulap, ongkèk, seblak sampur, serta tanjak. Keterikatan antara 
struktur gerak dasar berpola dengan pola karawitan terlihat jelas terutama pada jejer pertama yang selalu menggunakan Ketawang Gendhing Kabor Topèng Sléndro Nem. Ragam gerak sabetan baik untuk karakter alusan maupun gagahan hampir sama, hanya sedikit berbeda dalam dinamika dan temponya saja.

Gerak perang merupakan repertoar gerak yang terdapat dalam adegan perang. Gerak perang bebas merupakan gerak-gerak dalam adegan perang yang tidak terikat oleh iringan, sedangkan gerak perang berpola merupakan gerak-gerak dalam adegan perang yang terikat oleh bentuk iringan tertentu, pada wayang golek Menak Yogyakarta dikenal dengan istilah majeng beksan meskipun bentuk ini jarang sekali dilakukan. Di dalam ragam gerak perang berpola dapat dibagi menjadi dua, yaitu ragam gerak perang berpola untuk tokohtokoh utama, meskipun ragam gerak ini tidak selalu bahkan jarang ditampilkan, serta ragam gerak perang berpola geculan untuk abdi atau panakawan yang biasanya selalu ditampilkan. Ragam gerak perang berpola biasanya merupakan gerak maknawi dan ragam geraknya lebih banyak mengisi pola-pola instrumen kendhang. Gending yang digunakan biasanya berbentuk ladrang dan ketawang dengan susunan atau garap tertentu sesuai dengan kebutuhan.

Secara umum karakter musikal gendinggending karawitan terutama berkaitan dengan dimensi pertunjukan wayang golek Menak Yogyakarta sangat berbeda dengan ketika gendinggending karawitan disajikan dalam bentuk klenèngan. Di dalam karawitan untuk sajian wayang golek, para penabuh gamelan tidak cukup hanya mendengarkan kendang sebagai pemimpin atau pamurba, tetapi juga harus selalu memperhatikan dalang. Hal ini disebabkan bahwa dalam adegan lepas atau adegan-adegan selain jejer, banyak sekali improvisasi suasana yang memerlukan kepekaan rasa karena seringkali perubahan-perubahan garap, misalnya keras lirih, cepat lambat, dan sebagainya tidak selalu diawali oleh tanda dari kendhang, tetapi oleh sasmita dalang baik dari dhodhogan keprakan maupun gerak wayang atau juga vokal dalang.

Gaya pedesaan Ki Widiprayitnayang kemudian juga dianut dan dilanjutkan oleh Ki Sukarno mau- pun beberapa bekas muridnya sebagai penerus dalang wayang golek Menak di Yogyakarta, seperti Ki Sudarminta dan Ki Suparman sangat terbuka peluang untuk terjadinya interaksi antara pengrawit dan dalang dan lebih bersifat improvisasi sesaat. Interaksi tersebut bisa berupa kata-kata atau dialog, tetapi bisa juga diungkapkan melalui bentuk teknik tabuhan sebagai reaksi atas aksi yang diungkapkan oleh dalang dalam pertunjukannya, baik yang memang bermaksud untuk menjalin komunikasi verbal dengan pengrawit atau penonton, atau yang muncul berdasarkan pada tanggapan adegan sedang berlangsung. Sanggit-sanggit semacam ini jarang sekali bahkan tidak dipersiapkan atau diatur sebelumnya, di dalam dunia pedalangan dikenal dengan istilah sambung rasa yang hampir pasti dilakukan dalam setiap pertunjukan, meskipun tidak menjamin selalu berhasil. Bahkan tidak jarang penonton juga tidak bisa memahami, karena ada kalanya guyonan-guyonan yang diungkapkan hanyalah berdasarkan pada peristiwa yang dialami oleh para pengrawitnya, dan tentunya hanya merekalah yang memahaminya.

Menurut Sukarno, pada masa kejayaan Ki Widiprayitna para pendukung karawitan atau pengrawitnya termasuk pesindhèn bukanlah orangorang yang mempunyai keahlian atau tingkat ketrampilan teknis yang tinggi. Gending-gending yang digunakan dipilih gending-gending dengan tingkat kesulitan yang rendah, pola-pola gendèran maupun kendhangan juga merupakan bentuk-

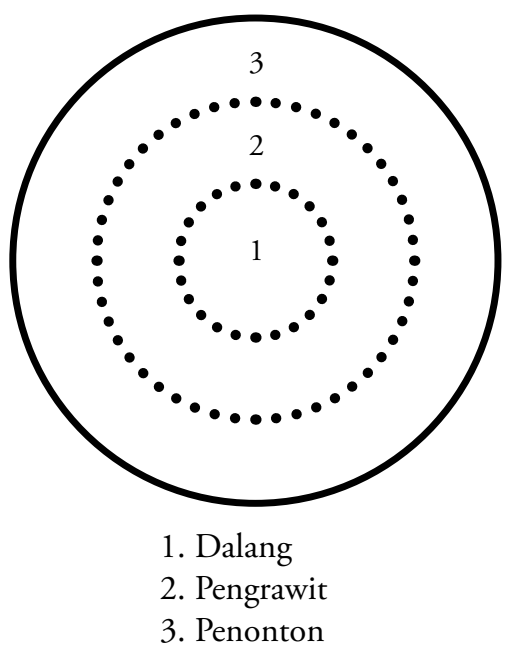

Gambar 2. Diagram lingkaran yang menunjukkan paradigm pertunjukan wayang golek Menak Yogyakarta (Dewanto Sukistono, 2013) 
bentuk yang sederhana, tetapi kekuatan mereka terletak pada kemampuannya memberikan daya hidup pada adegan yang sedang berlangsung, dalam istilah pedalangan sering disebut dengan istilah nyawiji dan manjing. Meskipun demikian, kesederhanaan tersebut bukanlah suatu hal yang mudah, diperlukan proses dan pengalaman karena pada kenyataannya pengrawit dengan tingkat ketrampilan teknis tinggi yang biasa menabuh gender atau kendhang dalam bentuk klenèngan, tidak serta merta atau menjamin mereka mampu menabuh gender atau kendhang untuk pertunjukan wayang. Oleh karena itu biasanya apabila dalang menerima tanggapan tetapi tidak komplit dengan pengrawitnya, minimal yang diajak adalah penggendèr dan pengendhang, sedangkan yang lain bisa seadanya. Kondisi ini tidak dapat dikatakan bahwa yang paling penting dalam penabuh adalah penggender dan pengendhang, tetapi keduanya merupakan skala prioritas keberadaannya.

Pada prinsipnya antara dalang dan pengrawit tidak ada yang mendominasi, mereka saling mengisi sebagai sebuah kesatuan bulat sehingga dimensi verbal antara suara gamelan dan dalang serta visualisasi pertunjukan terutama gerak berubah menjadi dimensi imajinatif. Di dalam kondisi ini maka bahkan penonton-pun juga merupakan satu kesatuan dari panggung pertunjukkan, dengan kata lain dalam konteks pertunjukan tidak ada lagi jarak atau batas yang tegas antara dalang, pengrawit dan penonton.

\section{Penutup}

Peran karawitan dalam setiap pertunjukan wayang golek Menak Yogyakarta tidak pernah bisa ditinggalkan. Karawitan merupakan pendukung utama pergelaran, tidak sekedar mengiringi, tetapi berperan penting menghidupkan suasana baik dalam adegan maupun karakterisasi tokoh. Beberapa ricikan atau instrumen gamelan lengkap yang biasanya digunakan dalam pergelaran wayang golek Menak adalah: gendèr barung, gendèr penerus, slenthem, kendhang, bonang barung, bonang penerus, gambang, suling, siter, rebab, kethuk kenong, kempul gong, demung, saron, peking, serta rojèh. Secara umum, struktur pertunjukan wayang golek Menak
Yogyakarta masih mengacu pada pertunjukan wayang kulit purwa gaya Yogyakarta, terutama dalam hal pathet berkaitan dengan pembagian adegannya, yaitu pathet Nem, pathet Sanga dan pathet Manyura.

Terdapat dua instrumen pokok yang menduduki posisi penting dalam karawitan wayang golek Menak Yogyakarta, yaitu gendèr dan kendhang. Peran gendèr lebih banyak memperkuat karakter yang berkaitan dengan suasana adegan, dan ditunjukkan dengan teknik permainan melodi instrumen gendèr berkaitan dengan vokal dalang seperti ada-ada, sulukan, atau untuk memberikan grimingan atau ilustrasi untuk memperkuat narasi serta dialog atau antawacana. Berbeda dengan gendèr, kendhang lebih banyak berperan secara komunal sebagai pemimpin untuk menghidupkan suasana terutama berkaitan dengan ekspresi sabetan atau gerak wayang dan melibatkan koordinasi dengan seluruh instrumen gamelan lainnya. Kelekatan antara 'warna' atau motif kendhangan dengan visualisasi ragam gerak wayang sangat mempengaruhi kualitas ekspresi rasa gerak yang diungkapkan.

Secara umum karakter musikal gendinggending karawitan terutama berkaitan dengan dimensi pertunjukan wayang golek Menak Yogyakarta sangat berbeda dengan ketika gending-gending karawitan disajikan dalam bentuk klenèngan. Di dalam pertunjukan wayang, perhatiaan pengrawit terutama tercurah lebih banyak pada peristiwa di atas panggung, selain tentunya kepada pengendhang sebagai pamurba irama. Gaya pedesaan Ki Widiprayitna yang kemudian dilanjutkan generasi penerusnya sangat terbuka peluang untuk terjadinya interaksi antara pengrawit dan dalang dan lebih bersifat improvisasi sesaat. Interaksi tersebut bisa berupa kata-kata atau dialog, tetapi bisa juga diungkapkan melalui bentuk teknik tabuhan sebagai reaksi atas aksi yang diungkapkan oleh dalang dalam pertunjukannya, baik yang memang bermaksud untuk menjalin komunikasi verbal dengan pengrawit atau penonton, atau yang muncul berdasarkan pada tanggapan adegan sedang berlangsung. Pada konteks ini, ketrampilan teknis penabuh bukanlah kunci pokok keberhasilannya sebagai pendukung 
utama, tetapi terjalinnya komunikasi sambung rasa antara dalang dan pengrawit sehingga dimensi verbal suara gamelan dan gerak wayang menyatu dan berubah menjadi dimensi imajinatif, yaitu dhalang nuksmèng wayang.

\section{Kepustakaan}

Abdullah, Irwan. 2006. Konstruksi dan Reproduksi Kebudayaan. Yogyakarta: Pustaka Pelajar.

Ardana, I Ketut. 2013. "Pengaruh Gamelan terhadap Baleganjur Semaradana" dalam Resital Jurnal Seni Pertunjukan, Vol.14 No.2Desember.

Brandon, James. R. 2003. Jejak-jejak Seni Pertunjukan Di Asia Tenggara. Bandung: P4ST UPI.

Dewey, John. 1980. Art as Experience. New York: Capricorn Books.

Fang, Liaw York. 1982. Sejarah Kesusastraan Melayu Klasik. Singapura: Pustaka Nasional PTE LTD.

Geertz, Clifford. 1973. The Interpretation of Cultutre. New York: Basic Book Inc.

Hastanto, Sri. 2009. Konsep Pathet Dalam Karawitan Jawa. Surakarta: ISI Press.

Humardani, SD. 1980. "Masalah-masalah Dasar Pengembangan Seni Tradisi”. Surakarta: ASKI.

Irawan. Endah. 2014. "Karakter Musikal Lagu Gedé Kepèsindènan Karawitan Sunda". dalam Resital Jurnal Seni Pertunjukan, Vol.15 No.1- Juni.
Mardiwarsito, L. 1978. Kamus Jawa Kuna (Kawi) - Indonesia. Jakarta: Nusa Indah Ende.

Martopangrawit. 1975. Pengetahuan Karawitan Jilid I. Surakarta: Akademi Seni Karawitan Indonesia.

Moris, Desmond. 1977. Man Watching: A Field Guide to Human Behavior. New York: Harry N. Abrams, INC Publishers.

Mudjanattistomo, dkk. 1977. Pedhalangan Ngayogyakarta. Yogyakarta: Yayasan Habirandha.

Poerwadarminta, W.J.S. 1939. Baoesastra Djawa, Batavia: B.Uitgevers-Maatschappij N.V. Groningen. 1984. Kamus Umum Bahasa Indonesia. Cetakan V (Jakarta: Balai Pustaka.

Soedarsono, R.M. 1997. Wayang Wong, Drama Tari Ritual Kenegaraan di Keraton Yogyakarta. Yogyakarta: Gadjah Mada University Press. 1999. Metodologi Penelitian Seni Pertunjukan dan Seni Rupa. Bandung: MSPI.

Tim Penulis Senawangi. 1999. Ensiklopedi Wayang Indonesia. Jilid III Jakarta:Senawangi,

Tim Penyusun Balai Bahasa Yogyakarta. 2001. Kamus Bahasa Jawa. Yogyakarta: Kanisius.

Tohir, Muhammad. 1979. Sejarah Islam dari Andalus sampai Indus, Jakarta:Pustaka Jaya.

Zoetmulder, P.J. dan S.O. Robson, 1995. Kamus Jawa Kuna Indonesia. Jakarta: Gramedia Pustaka Utama. 